tinct from and independent of the others, and its nature and object clearly indicated by a conspicuous label.

The exhibited specimens should be arranged in upright wall-cases or in table-cases on the floor of the room. For the latter a high slope is preferable, and in all the exhibition space should not extend too high or too low for comfortable inspection. Between three to six or seven feet from the floor should be the limits for the exhibition of small objects. The three feet nearest the floor may be inclosed with wooden doors forming cupboards or fitted with drawers. Glass in this situation is liable to be broken by the feet or knees.

The museum should have a permanent curator-a man of general scientific attainments, and who is specially acquainted with, and devoted to, museum work, and who might also be one of the teachers, if too much of his time is not so occupied. But, as he is not likely to have special knowledge of more than one branch of natural history, the teachers of the other branches represented in the museum would probably each give advice and assistance with regard to his own department. It is also probable that some of the boys may be sufficiently interested in the work to render valuable aid in collecting and preparing specimens.

If ethnographical, archæological, historical, or art collections be also part of the general museum scheme, they should be kept quite distinct from the natural history collections, preferably in another room.

Above all things, let the following words of Agassiz be remembered: "The value of a museum does not consist so much in the number as in the order and arrangement of the specimens contained in it."

W. H. FLOWER.

\section{THE FISHERY INDUSTRIES OF THE UNITED STATES.}

THE volumes which form the subject of the present article are the continuation of a complete monograph of the fisheries and fishing industries of the United States, of which the first and second sections have already been published under the titles of "A Natural History of Useful Aquatic Animals," and "A Geographical Review of the Fisheries of the United States."

The direction of the immense investigation necessary for the preparation of this work has been in the hands of Mr. G. Brown Goode, who, as early as I877, had drawn up a scheme for an exhaustive exploration of the coast of the United States in connection with the fishing industry. The enterprise was undertaken jointly by the United States Fish Commission and the Census Bureau, and the expenses of investigation, compilation, office and field work, and publication, have been shared by these two departments.

A work of this magnitude was quite beyond the powers of an individual, and we find accordingly that a number of authors, whose names are given at the back of the title-page, have been associated with Mr. Brown Goode in his undertaking. Among them are many names well known to science from their contributions to the natural history of the United States. Chief among these are Messrs. Marshall MacDonald, J. A. Ryder, and other members of the United States Fish Commission.

An English reader will invariably use his knowledge of British fisheries as a standard for comparison with those of a foreign country, and, in doing so, will find many difficulties, owing, not only to the difference in the species of fish which are found on the two sides of the Atlantic,

" "The Fisheries and Fishery Industries of the United States." By George Brown Goode, Assistant secretary of the Smithsonian Institute, and a staff of Associates. Section III. The Fishing-Grounds of North America, with 49 Charts, edited by Richard Rathbun. Section IV. The Fishermen of the United States, by George Brown Goode and Joseph W. Collins. Section V. History and Methods of the Fisheries; in Two Volumes, witl an Atlas of 255 Plates. (Washington: Government Printing Office, 1887.) but to the fact that many of our common names, such as pollack and hake, are applied to different fish in America, and that the Americans often use an altogether peculiar zoological nomenclature, which may throw even an experienced zoologist into confusion. Many American fishes of great commercial importance are unknown in Great Britain, such as the tautog (Tautoga onitis), the squeteague (Cynoscion regale), the blue-fish (Pomatomus saltator), the menhaden (Brevoortia tyrannus), and the shad (Clupea sapidissima). The most favourite edible crab of North America (Callinectes hastatus), the blue crab, is a perfectly distinct species from our common Cancer pagurus. and the American lobster (Homarus americamus) and oyster (Ostraa virginica) are different from our own. The European sole is unknown in American waters, as are our turbot and brill; the halibut, which has only recently become important in British fisheries, is of great importance in America, and their "plaice" (Paralichthys dentatus) differs entirely from the fish known to us by that name. These and many other differences in the species of marketable fish are important, as they serve in part to explain the different methods pursued by American fishermen; why, for instance, beam-trawling is unknown in their waters.

Of the third section of the monograph, which forms a half of the first of the four volumes under consideration, $\mathrm{Mr}$. Brown Goode himself says :- "It is the first report of the kind ever written. It describes the locations, the characteristics, and the productiveness of the numerous grounds resorted to by the fishermen of the United States, extending from Greenland to Mexico, from Lower California to Alaska, and including the fishing grounds of the great lakes." For the Atlantic seaboard this work is carried out on a scale of completeness never before attempted. Not only does the text abound with information relative to the different fishing grounds and banks, their history, productiveness, the character of their bottom, and the weather prevailing there at different seasons, but the whole of this is graphically represented in a series of admirable charts which form in themselves a complete fisherman's guide to the whole coast from Greenland to Mexico. In addition to this, the migrations of different species of fish from locality to locality are alluded to, and the characters of the invertebrate fauna are, in some instances, adduced in explanation of these migrations. It is impossible to criticize this part of the work : to do so one must have a thorough knowledge of all the principal fishing-grounds of America ; but, granted that the information and observations on which the charts and text are founded are correct, the method of displaying this information is unimpeachable.

Not the least valuable part of Section III. is the appendix containing the temperature observations from I $88 \mathrm{I}$ to 1885 inclusive. A word as to the manner of making these observations will not be out of place. The Census Bureau was, of course, unable to undertake this kind of work, and the Fish Commissioners, whose steamers were constantly engaged in expeditions to various localities, found that they could not keep a sufficiently continuous record of the temperatures observed at different points along the coast. Application was accordingly made to the United States Lighthouse Board and Signal Service, and these departments instructed their employés to make the required observations as part of their regular duties, and without extra compensation. The editor acknowledges the thoroughness with which these men performed the gratuitous services demanded of them, and the result is a large number of charts of temperature curves for each observing station, and charts showing the isothermal lines connecting the stations in different years.

The Pacific fisheries are dealt with in a much less complete manner, and are referred to as being undeveloped. The Alaskan fisheries are more fully dealt 
with, and have a special interest as forming the chief, if not the only means of subsistence of the native population. The methods of fishing adopted there are of the most primitive character, and very few civilized fishermen are employed in the industry. Fish, however, is exceedingly abundant, and its value is shown by the price of salmon (Onchorhynchus) in the Yukon River. Dried salmon is called ukati, and the best quality chowichee ukali. One chorvichee ukali is accounted a sufficient day's food for six men or dogs, and can be purchased for one leaf of tobacco, or five to eight musket-balls.

The fourth section of the monograph relates to the United States fishermen themselves. In I 880 there were IOI,684 bonâ fide professional fishermen in the United States, those men only being reckoned as fishermen who make more than half their income by fishing. At the same time there were in Great Britain and Ireland between 90,000 and 100,000 fishermen who would come under this definition. It appears that whalers and sealers are reckoned among the American fishermen, and as they are certainly not reckoned in the English computation, the number of men engaged in fishing, properly so called, would be about equal in the two countries. Of the United States fishermen, the majority, including the negroes of the Southern States, and the Alaskans, are native-born American citzens, while from Io to I2 per cent. are foreigners. The majority of the latter are natives of British provinces; the remainder are made up of Portuguese from the Azores, Scandinavians, Irish, and Englishmen, Italians, Indians, and, on the Pacific coast, Chinese. The chapters devoted to the fishermen of the different States are very interesting. The description of the Maine fishermen might be taken from any English fishing port. They are hardy, self-reliant, and honest, but are ill educated, inveterate grumblers, and entirely in the hands of the middleman. They will work hard when fishing, but are reluctant to undertake any other work, even for good pay. They marry early, and have large families, whilst their profits are low, the average annual return to each fisherman being \$175 (about £36).

Oyster-dredging seems to have a peculiarly demoralizing effect in the United States, the white oystermen of Maryland being reckoned as the lowest of their class. The New England fishermen are the best educated, the most enterprising, and the most successful in the United States. Unlike the majority of European fishermen, they do not form a class apart, and have no peculiar traits or characteristics marking them off from their fellow-countrymen. They are good men of business, and many of them have left the fishing trade altogether, and been highly successful in other branches of business. Their fishing-craft, nearly all schooner-rigged, are the finest and largest in the world, and their life on board is far more civilized and comfortable than anything met with in Europe. Their earnings are far higher than those of the Maine fishermen. A Gloucester man will commonly make $\$ 1000$ (more than $£ 200$ ) in a year, whilst skippers who are partly owners have on rare occasions made as much as $\$ 10,000$ to $\$ 15,000$ in a single year (from $£ 2000$ to $£ 3000$ ). Men living under such conditions are naturally of a high standard of intelligence, and the U.S. Fish Commission have profited largely from the co operation of the New England fishermen. They have from the first recognized the value of a scientific inquiry in fishing matters; have in many instances devoted themselves heartily to assisting the labours of the Commissioners; have kept regular records of their journeys, including observations on tides, temperatures, weather, and sea-bottoms; have collected the fauna of the different fishing-grounds, and otherwise have been instrumental in helping scientific observation. They have one and all been ready to profit by the information gained by the Commission, and have readily tried and adopted novel methods of fishing, such as gill-nets for cod-fishery, and purse-seines for.catching mackerel.

It is obvious, from a perusal of this volume, that the American fishermen are far more careful of their fish than Englishmen; they do not thump them down on the deck and stamp about on them, as is too commonly done on a British smack; they carefully clean them on board, and store them in proper receptacles, and, where fish is cured, it is commonly done on board when the fish is perfectly fresh. The reputation of the Gloucester, Mass., fishermen is curiously illustrated by a petition sent to the Lord-Lieutenant of Ireland this year. It was reported that several American schooners were coming to fish for mackerel off the coast of Ireland, and the fishermen, who do not fear the competition of English and French boats, were in great alarm lest the Americans with their purse-seines and large boats should utterly sweep the seas of fish.

Section IV. closes with a description of the dangers to which American fishermen are exposed, and an account of the management of fishing-craft. The whole is most interesting reading.

Section V. comprises two thick volumes of text and one of plates. The subjects it deals with range from whalefishing to sponge-gathering, from baiting hooks to preparing sardines. Each branch of the fishing industry is minutely described in the text ; the history of the fishery is given ; old and new methods are compared; the boats, crews, fishing-gear, methods of packing and curing on board are carefully explained, and the descriptions are supplemented by a profuse number of illustrations.

It will be unnecessary to follow the various branches of fishing in detail, but a few remarks on special forms of fishing will be of interest. As has been said above, the Americans have no beam-trawl fishery: the flat-fish which are so highly prized in Europe are either absent from the American shores, or are held in low estimation, and we find no special mention of flat-fish fisheries in this section, with the exception of the extensive fishery for halibut. There appears to be a prejudice against flat-fish in many parts of America, and there is certainly a prejudice against the use of the beam-trawl. If the latter were introduced, and the several flat-fishes which are abundant in some parts of the United States waters were thrown freely into the market, an important branch of fishery would no doubt be established. Halibut are caught in deep water by means of long lines, known in America as "trawls," just as they are by the Grimsby boats working in the neighbourhood of the Faroe Islands. The method of setting several long lines round the schooner by means of smaller boats called "dories," is well worth noticing, but the great risk to life entailed by the use of the "dories" is an objection to introducing this mode of fishing into British waters.

The cod-fishery of the United States is very large, and is carried on to a large extent on the Great Bank of Newfoundland, as well as on the Labrador and St. Lawrence coasts. There appears to be a fine cod-fishery off Alaska, but it has only been partially worked by a small fleet hailing from San Francisco. The cod-fishery was formerly, and still is to a large extent, carried on by hand lines and long lines, or "trawls," but in I880 the U.S. Fish Commission succeeded in introducing gill-nets, long since used by the Norwegians, among the fishermen of Gloucester. The obvious advantages of the cod gillnets are that they save the fishermen the trouble and expense of obtaining bait, which is often as difficult to procure as it is in England, and thus increase their profit; they are easily set and worked, they catch more than the long lines working on the same ground, and as the size of the mesh is adapted only for cod of a certain size, the small fish or "trash" pass through and escape. This is a good example of the practical usefulness of the U.S. Fish Commission. 
The accounts of the menhaden and mackerel fishing show that the Americans are as prone to complain of particular modes of fishing as English fishermen: the purse-seine is as obnoxious to some of them as the beamtrawl is in England, and the use of steam is at least equally unpopular. Steam is used chiefly in the menhaden fishery, and this, in combination with the purseseine, a net practically unknown in England, has, it is alleged, utterly destroyed the menhaden fishing in certain districts. This led to petitions to Congress for the protection of the menhaden fishery, and in $\mathrm{J} 882$ and 1883 the matter was inquired into, and protective legislation recommended. The evidence of actual decrease in the fishery does not appear in the Report on the fishery, but as the Commissioner of Fisheries was a member of the Committee which drew up the Report recommending legislative interference, it is to be presumed that he was satisfied that the fact of a diminution of the menhaden, due to over-fishing, was established.

Mackerel-fishing is conducted entirely by sailing-boats, most of them schooners of sixty tons register and upwards, and in these days it is carried on almost entirely by means of the purse-seine. In England, the summer fishing for mackerel is carried on by means of hand lines, and small boats may be seen "railing" or "whiffing" amongst the schools of mackerel. This method was formerly followed in America, but is now, to all intents and purposes, a thing of the past, the figures of small boats "jigging " and "drailing," as it is called in America, being given only in illustration of an obsolete industry.

The purse-seine first came into general use in 1850 , but its greatest development dates only from 1870, and since the latter date there has been great opposition to its use, on the score of its destructiveness. The statistics of the mackerel-fishery do not, however, warrant this opposition. Mackerel-fishing has always been uncertain, and, as early as 1660 , prohibitory laws of various kinds were passed to prevent, as it was supposed, the destruction of this industry. In 1838 , twelve years before the introduction of purse-seines, the catch of mackerel was very small, and then the blame was laid on "the barbarous method of taking mackerel called gigging." The largest take of mackerel in a single year was in I831, when 449,950 barrels of pickled mackerel were officially inspected; the second largest catch was in $188 \mathrm{I}$, when 391,657 barrels were inspected. The worst catch was in I 877 , when 127,898 barrels were inspected. A glance at the official tables shows that the fluctuations in the mackerel-fishery are quite independent of the usual method of fishing. The use of purse-seines might advantageously be tried in England, though it was found a failure by American schooners fishing off the Norwegian coasts, because, as it was alleged, the mackerel moved there in smaller schools than on the opposite side of the Atlantic.

In the second volume, on history and methods, English readers will find especial interest in the account of the great fur-seal industry of Alaska, which is regulated, as is well known, by a wise law prohibiting the destruction of more than a fixed number of seals every year.

No one who reads these volumes can fail to be struck with the practical national benefit of the United States Fish Commission. The production of this great work is only a small part of their active usefulness, but if it be judged by its utility alone, it is an exceedingly important part. When finished, this monograph of the fishing industry of the United States will form a complete textbook of American fisheries in all their branches, and will serve not only to interest the American public in a great national industry, but as a reliable guide to all those who are engaged in the fishing trade itself. In many cases it will be eminently serviceable as a book of reference to the practical fisherman, informing him of the localities and characteristics of fishing-grounds with which he is unacquainted, of the kinds and abundance of fish that he may expect there at different seasons, and of the best methods of prosecuting fisheries to which he is unaccustomed. Capitalists and manufacturers will learn from it how they may most profitably embark in a new industry, and the consumer will know from it how to judge of the quality of the article he consumes, and where to obtain it to the best advantage. It is impossible to refrain from drawing a comparison between this enlightened support given to an industry which from its very nature is incapable of being benefited by private effort, and the comparatively small support given by the English Government to our own fisheries, which, when the whale and seal fisheries are discounted, are at least of equal value with those of the United States. There are, indeed, signs that it is being generally recognized that the laissez faire policy as applied to national fisheries is a mistake. It is to be hoped that, when our Government takes another step forward, the example of the United States may not be lost sight of, and that, in addition to a central office with its necessary clerks and official administrators, a staff of skilled scientific investigators and practical men may be appointed, such as will be able to produce as exhaustive a work as that under review.

\section{NOTES.}

ON Friday evening last, Sir Lyon Playfair, having distributed the prizes and certificates gained by the students of the City of London College, delivered an interesting address, taking as his chief subject the need for vital improvements in English methods of education. There had been, he said, a marked change going on over the world in regard to work. Machinery had been taking the place of muscular labour. Less human labour was employed, but it was much better paid than formerly. The workman must adapt himself by trained intelligence to these changes, otherwise he would go to swell the ranks of unskilled labour. Foreign countries had been quicker awake to the changes that were going on than we had been. We were proposing technical education, while France, Germany, Belgium, and Switzerland had been adapting themselves to the altered state of things by improved schuols, secondary schools, commercial, building, and other special schools, which they had been promoting for many years. Germans and Frenchmen were taking places in English counting-houses, because the youth of London had not been educated in those languages which were necessary to commerce. We were now beginning to awake to the necessity of doing what was being done in other countries. Until comparatively lately we had nothing but classical schools. The learned classes had been entirely separated from the people; but the people's knowledge of trade improved science, and science improved trade. The learned classes were ignorant of this. This was not the way that the magnificent science and literature of Greece and Rome arose. Their great philosophers were busy in commerce, and were acquiring experience and knowledge among the masses of their own countrymen. This, he was rejoiced to see, was what we were now trying to bring about in this country.

THE formation of two new Microscopical Societies has recently been announced. One of these is the Scottish Microscopical Society, meeting in Edinburgh, with the following office-bearers : President Prof. Sir W. Turner; Vice-Presidents, Prof. Hamilton and Mr. Ad. Schulze; Secretaries, Dr. A. Edington and Mr. Geo. Brook. This Society has already held two successful meetings. The other Society is the Italian Microscopical Society, intended to bring together microscopists from the whole of Italy. The subjects for research, specially mentioned in the prospectus, are animal and vegetable histology, petrology, bacteriology, and the structure of the microscope and its appliances.

AT Leyden there is a fine ethnographical collection, which is especially valuable so far as it relates to the Dutch East Indian 